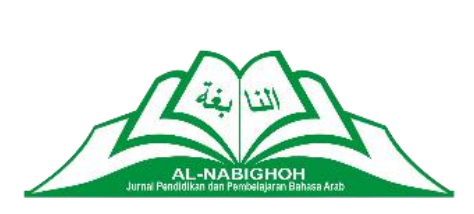

\title{
DEVELOPMENT OF MODULE SHARAF USING A DEDUCTIVE APPROACH IN THE DINIYYAH PUTRI LAMPUNG BOARDING SCHOOL
}

\author{
Mezan el-Khaeri Kesuma ${ }^{1 *}$, Era Octafiona ${ }^{2}$, Reni Puspita Sari ${ }^{3}$ \\ 1 Universitas Islam Negeri Raden Intan Lampung, Indonesia \\ ${ }^{2}$ Universitas Islam Negeri Raden Intan Lampung, Indonesia \\ ${ }^{3}$ Universitas Islam Negeri Raden Intan Lampung, Indonesia
}

\section{Article Info}

\section{Article History:}

Received: January 2021

Revised: May 2021

Accepted: June 2021

Published: June 2021

*Corresponding Author:

Name:

Mezan el-Khaeri Kesuma

Email:

mezan@radenintan.ac.id

\section{Abstract}

This research aims (1) to produce a sharaf module on fi'l mujarrad and fi'l mazid's material with a deductive approach that can be used as teaching material later, and (2) to test the feasibility of the product so it can be used effectively and efficiently. This research adopted the development research of Borg and Gall. This research was conducted at Diniyyah Putri Lampung Islamic Boarding School (PonPes), located in Negri Sakti Village, Gedong Tataan District, Pesawaran Regency, Lampung Province. The deductive approach in this module starts with the provision of rules that must be understood and memorized. Examples are given. After that, the students have been allowed to do exercises to apply the rules or formulas that have been given. Through seven stages of development, the researcher produced a product in the form of a sharaf module with a deductive approach at Ponpes Diniyyah Putri Lampung. The use of products in Sharaf modules developed in this study can make it easier for students to follow Sharaf subjects, especially in fi'l mujarrad and fi'l mazid materials, until students master the ability of qowa'id Sharaf.

Copyright (C) 2021, Mezan el-Khaeri Kesuma et al. This is an open-access article under the CC-BY-SA license 


\section{Introduction}

Islamic Boarding School (PonPes) Diniyyah Putri Lampung is one of the schools that implement education that aligns Madrasahs with Islamic boarding schools. All students are required to live in the Pondok so that all students who go to school in that place are obliged to participate in Pondok activities.

PonPes Diniyyah Putri Lampung has several unique skills / personal development, including language, especially English and Arabic. Thus, the curriculum applied in Madrasah is different from SMP in general. This difference can be seen from the subjects taught to students other than subjects in public schools. Some issues aim to facilitate students to explore Arabic, such as Nahwu, Sharaf, Mahfudhot, and Balaghah.

According to Supriadi et al., grammar is one of the problems experienced by students in any school because Arabic grammar must know the formula and the key to understanding this science. Like nahwu and sharaf, which are the key to understanding Arabic grammar. ${ }^{1}$ One of the sciences of Pure Linguistics in learning Arabic is Sharaf, a subject that studies morphology in Arabic. According to Muhajirun Najah, the word morphology comes from the word morph, which means 'form', and logy, which means 'knowledge'. However, in linguistic studies, morphology refers to the study of language forms. ${ }^{2}$ Rahmawati and Rahmi explained that morphology is a part of linguistics that examines the level of features with grammatical, morphological processes to replace lexemes and lexical with words. The morphology in Arabic is different from the morphology of other languages; in the essential parts of the Arabic morphology, there are systematic rules. $^{3}$

Learning sharaf or morphology is sometimes considered easy to understand for beginner-level Arabic learners so that this subject is being taught in various schools. One of them in PonPes Diniyyah Putri Lampung has studied since grade 2 SMP (MTs). Even though it is deemed manageable, many students also think learning to sharaf be a scourge because it has never achieved satisfactory scores in exams or tests. For educators, it becomes confusion and anxiety due to the inability of students to properly absorb the material presented even though various kinds have been used-a well-known method for achieving the success of the teaching and learning process.

${ }^{1}$ Agus Supriadi, Akla Akla, dan J. Sutarjo, “Problematika Pengajaran Bahasa Arab Di Madrasah Aliyah," An Nabighoh: Jurnal Pendidikan Dan Pembelajaran Bahasa Arab 22, no. 02 (2020): 211, https://doi.org/10.32332/an-nabighoh.v22i02.2314.

2 Muhajirun Najah, "Penerapan Pembelajaran Shorof Bagi Pembelajar Tingkat Pemula Menggunakan Metode Pemerolehan Bahasa," Al Mahāra: Jurnal Pendidikan Bahasa Arab 5, no. 1 (2019): 117, https://doi.org/10.14421/almahara.2019.051-07.

3 R. A. Putri Rahmawati dan Novita Rahmi, "Analisis Kesalahan Morfologi Dalam Insya," An Nabighoh: Jurnal Pendidikan Dan Pembelajaran Bahasa Arab 22, no. 02 (2020): 243, https://doi.org/10.32332/an-nabighoh.v22i02.2311. 
According to Najah, the problems experienced in studying Sharaf include; From the learner's point of view: a) Discussion that quickly changes. b) Rote learning. c) Multiple patterns of changing words. d) mufradat (Arabic Vocabulary) that has changed from its original form is rarely used in everyday life. And from the educator's point of view: a) Students have not mastered the material where the letters come out when reading the Al-Qur'an, Arabic, or hijayah letters (makhorijul huruf). b) Students are not the same as mastering fi'l Arabic. c) Material that is difficult to explain using the method mubasyaroh (Direct method). ${ }^{4}$

Based on the results of observations, the researcher conducted a preresearch in the form of interviews and questionnaires at PonPes Diniyyah Putri Lampung. Pre-research, there were problems with students who had not mastered the material and had problems learning fi'l. Plus it is known that the textbooks used so far do not allow students to learn independently. The material contained in printed books is less systematic. It does not have many examples of sentences in each chapter, and exercises are not by the learning objectives because the book does not include learning objectives that students will achieve. This can lead to the low ability of the Sharaf of students; for example, students are less able to make examples of sentences in which there are fi'l mujarrod and fi'l mazid correctly.

For students to be able to understand and apply material sharaf, it takes a lot of examples and exercises that are presented in the book sharaf, because the purpose of learning sharaf, in general, is to know the change in the origin of words into several kinds of words as well as knowing how it changes according to word form patterns and to avoid some errors related to problems nerve.

Rowntree (1994), in Sadjati on the other hand, has a slightly different point of view from the two experts above in classifying this type of teaching material. According to Rowntree, the kinds of teaching materials can be grouped into 4 (four) groups based on their nature, namely: (1) Print-based teaching materials, including books, pamphlets, student study guides, tutorial materials, student workbooks, maps, charts, photos, material from magazines and newspapers, etc .; (2) Technology-based teaching materials, such as audio cassettes, radio broadcasts, slides, filmstrips, film, video cassettes, television broadcasts, interactive video, Computer Based Tutorial (CBT) and multimedia; (3) Teaching materials used for practice or projects, such as science kits, observation sheets, interview sheets, and so on; (4) Teaching materials needed for human interaction (especially in distance education), for example, telephone and video conferencing. ${ }^{5}$

From the above statement, the authors conclude that there are two types of teaching materials, namely printed and non-printed teaching materials. The

\footnotetext{
4 Najah, "Penerapan Pembelajaran Shorof Bagi Pembelajar Tingkat Pemula Menggunakan Metode Pemerolehan Bahasa."

${ }^{5}$ Ida Malati Sadjati, "Hakikat Bahan Ajar," dalam Pengembangan Bahan Ajar (Jakarta: Universitas Terbuka, 2012).
} 
printed teaching materials in question are modules, handouts, and worksheets. The following are the characteristics of the three:

\begin{tabular}{|c|c|c|}
\hline No. & $\begin{array}{l}\text { Types of Printed Teaching } \\
\text { Materials }\end{array}$ & Characteristics \\
\hline 1 & Module & $\begin{array}{l}\text { It consists of a variety of written materials used for } \\
\text { independent study. }\end{array}$ \\
\hline 2 & Handout & $\begin{array}{l}\text { It is a variety of printed materials that can provide } \\
\text { information to students. Handout This usually deals with } \\
\text { the material being taught. In general, this handout consists } \\
\text { of notes (both complete and outline only), tables, } \\
\text { diagrams, maps, and other additional material. }\end{array}$ \\
\hline 3 & $\begin{array}{l}\text { Student Worksheets } \\
\text { (LKS) }\end{array}$ & $\begin{array}{l}\text { includes case sheets, reading lists, practicum sheets, } \\
\text { briefing sheets about projects and seminars, worksheets, } \\
\text { and others. These worksheets can be used for a variety of } \\
\text { learning situations. }\end{array}$ \\
\hline
\end{tabular}

So it is necessary to have printed teaching materials in the form of modules that allow students to learn independently and help them more easily understand material sharaf. There are many example sentences in the module and do exercises in each chapter that are tailored to the learning objectives. Modules are a learning component that educators must adequately prepare. Module development is significant in educational practice. Things that must be considered in module development must match the goals and needs of students.

To provide teaching sharaf effectively in schools, one of the abilities that educators have in carrying out their duties is to develop textbooks in the form of modules according to students' needs and characteristics to create quality, conducive, meaningful and enjoyable learning. Based on Mujab's research results, the purpose of teaching using modules is to provide opportunities for students to learn according to their speed and method because they can use several different techniques to solve problems. ${ }^{6}$ Furthermore, the results of Sica Septyenthi's research, the use of modules can also increase motivation because one of the characteristics of the module, namely self-instruction, is to produce modules that allow someone to learn independently. ${ }^{7}$

Therefore, Neuroscience is an essential study in which it concerns the structure of language. Several approaches can be used in teaching sharaf, namely the deductive method. The reasoned approach is a learning approach sharaf that

${ }^{6}$ Ahmad Saiful Mujab, Retno Purnama Irawati, dan Nailur Rahmawati, "Pengembangan Modul Bahasa Arab Berbasis Teori Psikologi Perkembangan Remaja Elizabeth B. Hurlock Kelas X MA," Lisanul Arab: Journal of Arabic Learning and Teaching 7, no. 1 (2018): 1-7, https://doi.org/10.15294/la.v7i1.26068.

${ }^{7}$ Sica Septyenthi, Aprizal Lukman, dan Upik Yelianti, "Pengembangan Modul Pembelajaran IPA Berbasis Entrepreneurship Di SMK Negeri 2 Kota Jambi," Edu-Sains: Jurnal Pendidikan Matematika Dan IImu Pengetahuan Alam 3, no. 2 (2014), https://doi.org/10.22437/jmpmipa.v3i2.1893. 
presents principles first then examples. ${ }^{8}$ Here are some studies related to Sharaf and the Deductive approach:

\begin{tabular}{clc}
\hline No. & \multicolumn{1}{c}{ Title } & Publication \\
\hline 1 & Model Language Learning Materials al-Arab al-Nahwiyyah Qawa'id. ${ }^{9}$ & Article Journal \\
\hline 2 & $\begin{array}{l}\text { Module Development Sharaf With Approach Deductive Modern } \\
\text { Pondok Madinah Lampung. }{ }^{10}\end{array}$ & Article Journal \\
\hline & $\begin{array}{l}\text { Development of Instructional Materials Structure Algebra-Based } \\
\text { Deductive Approach To Improve Hot Skills of the Student University } \\
\text { of Riau Islands (Unrika) Batam. }{ }^{11}\end{array}$ & Article Journal \\
\hline & $\begin{array}{l}\text { Application of Deductive Methods in Class 5 Nahwu Learning at Al- } \\
\text { Ishlah Islamic Boarding School, Alislami Assalafi, Mangkulon, } \\
\text { Semarang (Fi'il Muta'addi and Fi'il Lazim Learning). }{ }^{12}\end{array}$ & Thesis \\
\hline
\end{tabular}

Based on the table above, the study of deductive Sharaf's has never been studied by other researchers. Currently, only researchers have studied Deductive Neurology. The general purpose The development of this module is to produce a product in the form of a module Sharaf with a deductive approach for PonPes students Diniyyah Putri Lampung. In particular, the purpose of this study was to find out the practicality, validity, and effectiveness of the module Sharaf with a deductive approach for PonPes students Diniyyah Putri Lampung.

One of the needs of students related to the module sharaf is exercises following the learning objectives and examples of sentences in each chapter. The need for educators as module users is an expansion of the material's content related to the discussion of sharaf so that educators have a broad knowledge of learning sharaf and not just teaching material contained in printed books.

\section{The Theory}

The basis of the module is a package of teaching materials that are presented systematically so that learners can learn independently without the guidance of an educator. Thus, a module must be used as teaching material as a substitute for the function of an educator. If an educator acts as a facilitator in explaining something,

\footnotetext{
${ }^{8}$ Isnainiyah, "Pengembangan Kitab Matan Al-Jurumiyah Dengan Pendekatan Induktif Untuk Siswi Madrasah Diniyah Nurul Ulum" 3 (2019): 1-19, https://prosiding.arabum.com/index.php/semnasbama/article/view/422.

${ }^{9}$ Ubaid Ridlo, "Model Pembelajaran Bahasa Arab Materi Al-Qawa'id al-Nahwiyyah," Al-Ma'rifah 12, no. 2 (2015): 46-57, https://doi.org/10.21009/almakrifah.12.02.05.

10 Mezan Kesuma dan Reni Puspita Sari, "Pengembangan Modul Sharaf Dengan Pendekatan Deduktif Di Pondok Modern Madinah Lampung," Studi Arab 11, no. 1 (2020): 27-36, https://doi.org/10.35891/sa.v11i1.1944.

${ }^{11}$ Nina Agustyaningrum dan Yessy Yusnita, "Pengembangan Bahan Ajar Struktur Aljabar Berbasis Pendekatan Deduktif Untuk Meningkatkan Hot Skill Mahasiswa Universitas Riau Kepulauan (Unrika) Batam," Jurnal Dimensi 6, no. 2 (2017), https://doi.org/10.33373/dms.v6i2.1045.

12 Yusup Purnomo, "Penerapan Metode Deduktif Pada Pembelajaran Nahwu Kelas 5 Pada Pondok Pesantren Al-Ishlah, Alislami Assalafi, Mangkangkulon, Semarang (Pembelajaran Fi'il Muta'addi Dan Fi'il Lazim)" (Skripsi, IAIN Walisongo, 2012), http://eprints.walisongo.ac.id/727/.
} 
the module must be able to explain something in a language that is easily understood by students according to their level of knowledge and age. ${ }^{13}$

Asyhar argues that a module is a form of printed teaching materials arranged and can be used by students to learn independently. Therefore, the module is equipped with instructions for self-study in this case so that students can learn independently without the presence of a teacher. ${ }^{14}$ Meanwhile, according to Abdul Majid, a module will be helpful if students can use it easily. Thus, the content of a module must be presented in good and interesting language and equipped with illustrations, and contains the basic competencies that students will achieve. ${ }^{15}$

The function of the module in learning activities is as follows: (1) Independent teaching materials, the use of modules can help students to improve their abilities according to their learning speed, (2) instead of teaching functions, the module must explain the learning material well and be easy to understand by students according to their level of knowledge and age, (3) Evaluation tools, students are required to be able to measure and assess their level of mastery of the material being studied, (4) Reference materials for students. Modules contain various materials that students must learn to improve the abilities that become competency standards. ${ }^{16}$

The module is said to be good if it meets the module criteria. The criteria for a suitable module are modules that must be structured systematically, which include: (1) The objectives that must be achieved, namely formulated in the form of particular behavior so that students' success can be measured, (2) Instructions for use, namely references for students to learn to use modules, (3) Learning activities, which contain material that students must learn, (4) Summary of material, namely essential points related to the subject matter, (5) Assignments and exercises, (6) Reading sources, namely reading books which must be studied to increase and deepen knowledge, (7) Tests or questions that must be done to determine the success rate of students in mastering the subject matter, (8) Success criteria, namely the level of success of students in learning modules, 9) Answer keys. ${ }^{17}$

Besides having advantages, according to Morrison, Ross, \& Kemp, the module also has several weaknesses, including (1) reduced interaction between students so that group learning activities are needed, (2) the existence of an independent approach can cause students to get bored because those challenging and varied problems are needed, (3) free independence makes students lazy and neglects

13 Departemen Pendidikan Nasional, Panduan Pengembangan Bahan Ajar (Jakarta: Direktorat Pembinaan Sekolah Menengah Atas, 2008).

14 Septyenthi, Lukman, dan Yelianti, "Pengembangan Modul Pembelajaran IPA Berbasis Entrepreneurship Di SMK Negeri 2 Kota Jambi."

${ }^{15}$ Abdul Majid, Perencanan Pembelajaran (Bandung: PT. Remaja Rosdakarya, 2008).

${ }^{16}$ Andi Prastowo, Panduan Kreatif Membuat Bahan Ajar Inovatif (Yogyakarta: Diva Press, 2015).

${ }^{17}$ Wina Sanjaya, Media Komunikasi (Jakarta: Kencana Prenada Media Group, 2012). 
various tasks, so that time limits are needed for learning, (4) module design must be optimal, requires teamwork and infrastructure support, either in the form of media or other sources, and (5) material preparation is more expensive when compared to the use of the lecture method. ${ }^{18}$

In the language of the word Sharaf or tasrif means to change or shift; changing the original form of the term to other forms to obtain meaning can be achieved by a change. According to Azhar, quoted by Fakhrurozy, the science of Sharaf is a science that discusses the structure of words and the authenticity of the letters, both additions, deletions, replacements, and changes. ${ }^{19}$

Imaduddin and Akhmad said that one of the morphological studies of Arabic (ilm 'sharf) is Verb (fi't). The fi'l is a sentence that shows the meaning of work at a specific time or time. According to the letter number, fi'l is divided into two, namely sulasi and ruba'I. In contrast, in terms of authenticity, verb letters in Arabic are classified into two types: fi 'I mujarrad and f'il mazid. Fi'l mujarrad original. The original meaning is $f^{\prime} l$ whose supporting letters here are fi'l whose letters are without additions. The fi'l whose supporting letters have been added to the original is called fi'l mazid. ${ }^{20}$ The objectives of studying Sharaf are (1) understanding Arabic, (2) understanding the contents of the Koran and al-Hadith, (3) making it easier to read yellow or bald books that have no vowels. ${ }^{21}$

Based on the explanation above, the researcher feels that students need development in a deductive approach module in learning Arabic, especially Sharaf. The objectives: (1) to determine the development of the module Sharaf based on a deductive approach, and (2) to make it easier for students to learn Sharaf.

\section{Method}

The research used is the Research \& Development $(R \& D)$ method, which in language means research and development methods. According to Sugiyono, $R \& D$ is a research method used by research that produces certain products and tests the effectiveness of these products. ${ }^{22}$ This study followed a research and development procedure according to Borg \& Gall (1989), which was limited to involving only the

${ }^{18}$ Lasmiyati Lasmiyati dan Idris Harta, “Pengembangan Modul Pembelajaran Untuk Meningkatkan Pemahaman Konsep Dan Minat SMP," Pythagoras: Jurnal Pendidikan Matematika 9, no. 2 (2014): 161, https://journal.uny.ac.id/index.php/pythagoras/article/view/9077.

${ }^{19}$ M. Imam Fakhrurrozy, "Nahwu Dan Shorof Perspektif Pembelajar Bahasa Kedua," Semnasbama (Seminar Nasional Bahasa Arab ) II 2 (2018): 103, https://prosiding.arabum.com/index.php/semnasbama/article/view/186.

20 Asbarin, Dita Armitha Sari, dan Kumillaela, "Kajian Morfologi Dan Pengaruhnya Terhadap Perubahan Makna (Analisa Buku Al 'Arabiyah Baina Yadaika)," Semnasbama (Seminar Nasional Bahasa Arab ) // 2 (2018): 344, http://prosiding.arab-um.com/index.php/semnasbama/article/view/208.

21 Limas Dodi, "Metode Pengajaran Nahwu Shorof; Ber-Kaca Dari Pengalaman Pesantren," Tafáqquh: Jurnal Penelitian Dan Kajian Keislaman 1, no. 1 (2013): 100-122, http://jurnal.iaibafa.ac.id/index.php/tafaqquh/article/view/7.

22 Sugiyono, Metode Penelitian Pendidikan (Pendekatan Kualitatif, Kuantitatif dan R\&D) (Bandung: Alfabeta, 2012). 
research and data collection stages (needs analysis), planning, preliminary product development, preliminary trials, and significant product revisions. ${ }^{23}$

This research and development aim to produce modules sharaf on fi'l mujarrad and fi'l mazid materials with a deductive approach which can later be used as teaching materials and testing the feasibility of products so that they can be used effectively and efficiently. The procedure for developing a module sharaf with a deductive approach to improving the abilities of nervous students uses the Borg \& Gall model with the reduction of the last three stages so that the following stages are presented:

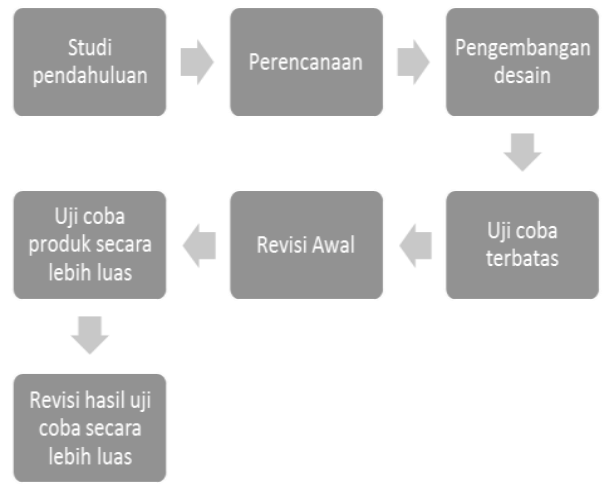

Figure 1. Research and Development Stage of the Borg \& Gall Model (2003) in Amirzan. ${ }^{24}$

The seven stages carried out in this study are as follows:

1) Preliminary study Preliminary

Studies conducted to obtain information in research and product development include needs analysis, literature review, research on a small scale.

2) Planning the research.

Planning the research carried out, namely formulating research objectives; estimate the funds, time, and energy that will be spent; specify the details of the products to be loaded; and determining who will be involved in the development process.

3) Design development

The module sharaf is structured using a deductive approach. Then the product design in it is as attractive as possible using the Coreldraw application by loading the material fi'l mujarrod and fi'l mazid, which refers to the competency standard (SK) and basic competence (KD). In addition to the material, the module also contains exercise questions and summative

${ }^{23}$ I. F. Ntelok, I. B. N. Sudria, dan I. W. Suja, "Pengembangan Perangkat Pembelajaran Saintifik Dengan Model Pembelajaran Problem Solving Melalui Penalaran Deduktif Pada Topik Laju Reaksi," Jurnal Pendidikan Kimia Undiksha 2, no. 1 (2018): 28-39, https://doi.org/10.23887/jjpk.v2i1.21182.

${ }^{24}$ Amirzan Amirzan, "Pengembangan Model Pembelajaran Gerak Dasar Lokomotor Pada Siswa SD Kelas V," Journal Physical Education, Health and Recreation 2, no. 1 (2017): 85-96, https://doi.org/10.24114/pjkr.v2i1.7843. 
evaluation to make it easier for students to learn independently without teacher guidance.

4) Limited

Trial This stage is a limited product test by conducting an initial field test of the product design, little to the substance of the design and the parties involved. Field trials were carried out to obtain input and responses to the products being developed. This trial was carried out by material experts and design experts, each of which was validated by two validators.

5) Initial Revision

This step represents a design improvement based on a limited field test. After knowing the weaknesses and shortcomings of these products, it is necessary to make improvements. This improvement is more directed at the appropriateness of the product content, based on input or feedback from the validators.

6) Broader product trials

After the refinement of the product in the previous stage, a product trial was carried out involving a more comprehensive range of parties than a limited trial. At this stage, large and small group trials were carried out to determine the product's feasibility, including substance and methodology.

7) Broader

Revision of trial results This revision of test results is the second improvement after the predecessor field test was conducted. Product improvement from the results of a broader field test will further strengthen the product being developed. Products that have been declared feasible can be used independently in the learning process both outside and inside the classroom.

To find out the feasibility of the module, the following formula is used: 25

$$
\mathrm{KN}=\stackrel{\stackrel{\mathrm{IJ}}{\mathrm{SS}}}{\mathrm{x}} 100 \%
$$

Information:

$\mathrm{KN}=$ Achievement Value

$\mathrm{J}=$ Number of correct answers to respondents in item

$\mathrm{S}=$ Number of questions in items

Meanwhile, to determine the effectiveness of using modules that have been developed, the data will be collected. Analysis using paired sample t-test through the statistical application (SPSS) with a significance level of 5\%.

Researchers researched at the Diniyyah Putri Lampung Islamic Boarding School, which is located in Negri Sakti Village, Gedong Tataan District, Pesawaran Regency, Lampung Province. This research was conducted for approximately six

25 Enik Setianingsih, Widha Sunarno, dan Sukarmin Sukarmin, "Pengembangan Modul Pembelajaran Dinamika Gerak Berbasis Inkuiri Terbimbing Untuk Siswa Kelas X SMA/MA," INKUIRI: Jurnal Pendidikan IPA 7, no. 2 (2018): 220, https://doi.org/10.20961/inkuiri.v7i2.22978. 
months (January to June 2020). The study was conducted by taking a population of 80 class X students of Senior High School (1 KMI). The sample taken was ten smallscale trials and 30 large-scale class X (1 KMI) students at PonPes Diniyyah Putri Lampung.

\section{Results and Discussion}

In this study, the resulting teaching materials in the form of modules Sharaf on the fi'l mujarrod and fi'l mazid were designed using a deductive approach. The results obtained showed that the criteria were very feasible to use. The development of the module Sharaf with a reasoned approach uses the Borg \& Gall model, which consists of 10 stages, with the reduction of the last three stages so that the following stages are presented:

The preliminary study is where researchers obtain information in research and product development through observation techniques at PonPes Diniyyah Putri Lampung, then conducted a written interview with educator PonPes sharaf Diniyyah Putri Lampung, and also gave a needs questionnaire to class X students (1 KMI). The results obtained are: First, the textbooks used so far do not allow students to learn independently. Second, the material presented in the printed book is less systematic and does not contain many examples of sentences in each chapter. Exercises are not under the learning objectives because the book does not prevent learning objectives that students will achieve. Third, the low ability of sharaf, such as students are less able to make examples of sentences in which there are fi'l mujarrod and fi'l mazid correctly and adequately. The results obtained indicate the potential to develop more exciting and efficient modules to help and make it easier for students to understand the subject matter.

The next stage of planning, namely the researcher planning research on the development of the module sharaf with a deductive approach to the material of $f^{\prime} l$ mujarrod and fi'l mazid such as estimating time, funds, and energy to be spent, details of the product to be published, and determining the parties to be involved. The next stage is product design. After knowing the problems in the field and collecting data related to research, information about the module product development Sharaf with a deductive approach will be developed. This design development resulted in the initial product. The existing teaching materials were further developed into modules with a reasoned approach, in which several materials and sample sentences were presented along with exercises tailored to the learning objectives.

The next stage is design development; the main steps taken are (1) determining the material to be developed, (2) formulating sub-material, (3) compiling practice questions and evaluation, (4) designing the design with a deductive approach, and (5) arrange the completeness of the material. 
The next stage is product validation by several experts, including material expert validators and design experts, each expert consisting of two validators. Verification is carried out to collect information, suggestions, and input about the product to be used as material for improvement. The product developed is suitable for use as a module nerve. The validator assesses the module assessment questionnaire Sharaf with a deductive approach at the Diniyyah Putri Lampung Islamic Boarding School. It provides input on the module Sharaf created by the researcher. In the initial product, the result of material expert validation was $77 \%$, design expert validation got an assessment of $76 \%$ with feasible criteria. The next stage of the product was tested for 10 to 30 students, from each class X (1 KMI) at Pondok Pesantren Diniyyah Putri Lampung. Students provide an evaluation after students use the module Sharaf. Assessment is carried out after learning to understand better in assessing and providing suggestions for module Sharaf. The results obtained from the student's evaluation of the module Sharaf received an assessment of $80.1 \%$ with proper criteria.

After validating with several validators, the next step is product revision. The suggestions and input obtained from several validators during validation are used to revise or improve the product being developed. The material expert gave tips, including adding ma'ani wazan to example sentences of material fi'l mazid, giving mufradat (Arabic Vocabulary) at the end of each material after the section tadribat, and adding boxes in the section tadribat. Design experts gave suggestions, including changing the front cover design to suit the module content, adapting the back cover design to the front cover, adding to the module description, fixing the schemes, Arabic fonts, and thickening the Arabic font size. After the module revision stage was developed, the researcher gave a reassessment questionnaire to the validator; the material expert's assessment score was $77 \%$ to $90 \%$. The design expert's assessment score was $76 \%$ to $83 \%$, with very feasible criteria.

The next stage is the small-scale test. The small scale trial consisted of 10 students of class X (1 KMI) PonPes Diniyyah Putri Lampung. After conducting small-scale trials, the next step is product revision. The results were obtained on a small-scale test, namely getting an assessment of $86 \%$ with very feasible criteriafurthermore, one educator mental and 30 class X students ( $1 \mathrm{KMI}$ ). The results of this trial are carried out to obtain assessments, suggestions, and input regarding the product being developed to serve as reference material for product improvement/revision to make it better and of higher quality. The assessment results of Sharaf educators of sharaf were $86 \%$, and the results of the assessment of 30 students were $90 \%$ with very feasible criteria. Based on the results of calculations using the SPSS application, it is known that the t value is 15.288 , and the $t$ table is 1.69913 with a significant level of $5 \%$. So it can be concluded that $t$ count $15.288 \geq$ from $t$ table 1.69913 shows a difference between the scores pretest and posttest of class X students (1 KMI) because Ha is accepted and Ho is rejected. 
The last stage is the second revision of the product developed based on advice and input from educators sharf PonPesDiniyyah Putri Lampung, namely: every tadribat was given vowel and meaning and increase mufradat (Arabic Vocabulary) in each Tashrif lughowi and Tasrif istilahi. Then suggestions and input from PonPesDiniyyah Putri Lampung students include: adding material coverage other than fi'l mujarrod and fi'l mazid in the module. However, this input cannot be used as material for revision due to the limitations of researchers in developing products.

After going through seven stages of development, the researcher produced a product in the form of a module sharaf with a deductive approach at Ponpes Diniyyah Putri Lampung. The use of products in the form of modules sharaf developed in this study can facilitate students in following subjects, sharaf especially in the material of fi'l mujarrad and fi'l mazid until finally students master the ability of qowa'id sharaf.

Based on the material expert test results and the results of the media expert's test above, module Sharaf is categorized as feasible to be produced after revision and improvement following expert/expert advice. A product trial in a small class is carried out as a form of initial evaluation before being tested in a large class with a score of $80.1 \%$; the category is feasible to be tested. The extensive class test is carried out to evaluate the module product design with $90 \%$ in the possible variety. Based on the feasibility test questionnaire that has been carried out, it can be concluded that the product in the form of a module sharaf with a deductive approach at the Diniyyah Putri Lampung Islamic Boarding School is suitable for module use. The sharaf with this reasoned approach has various benefits that are better than other modules. Students find it easy to learn the material because each student can learn the textile directly and independently without the help or presence of an educator. This module is flexible because it is easy to use at any time, equipped with learning materials that have been adjusted to the KD; there are many examples of sentences with wazan meanings and exercises that are tailored to the learning objectives and contain mufradat (Arabic Vocabulary) at the end of the material.

\section{Research Limitations}

By realizing the shortcomings and limitations in carrying out research, it is deemed necessary to consider it as necessary. The rules in this study are: (1) At the commencement of this study, namely in June 2020, Indonesia, especially Lampung, was hit by the Covid-19 pandemic outbreak. Access and data retrieval have been hampered due to this pandemic. Students are still at the lodge when researchers research by prioritizing the Covid-19 protocol standard, (2) Researchers (educators) and students are still unable to adjust because of the pandemic situation. So that there are some students who are difficult to control in the 
learning process. Researchers do not know students, as well as students do not know researchers. Some of them even think that researchers are PPL educators, (3) The learning process and conditions do not fully meet the criteria for the cooperative model, namely that not all groups discuss with friends so that it can affect student learning outcomes, (4) Students are not used to the following learning by using groups and independently. So that some groups and individuals do not work optimally, (5) during the pretest and posttest, there may be students who work together or cheat. This, of course, causes that the value obtained is not entirely the result of previous treatment.

\section{Conclusion}

After going through seven stages of development, the conclusion that can be conveyed is that the researcher produced a product in the form of a sharaf module with a deductive approach in the Diniyyah Putri Lampung Islamic Boarding School. The use of products in the form of sharaf modules developed in this study can facilitate students in following sharaf subjects, especially in the material of $f^{\prime \prime} l$ mujarrad and fi'l mazid, until finally, students master the ability of qowa'id sharaf. The results of the material expert test and the results of the media expert test are categorized as feasible to be produced after revisions and improvements by expert advice. Product trials in small classes are carried out as a form of initial evaluation before being tested in extensive courses with a score of $80.1 \%$; the category is feasible to be tested. The significant class test is carried out to evaluate the module product design with $90 \%$ in the viable variety. Based on the feasibility test questionnaire that has been carried out, it can be concluded that the product in the form of a sharaf module with a deductive approach in Ponpes Diniyyah Putri Lampung is suitable for use.

Based on the research results obtained and the weaknesses and limitations of this study, the researcher provides the following suggestions: (1) This research is expected to be carried out before or after the pandemic; moreover, students must be in school. And it is not suitable for online learning models, (2) paying attention to variables that might interfere with the learning process, it is hoped that the school will set the Sharaf subject schedule at the beginning of class hours without reducing the number of hours as during this pandemic, (3) Therefore, when learning uses the Deductive approach, educators do not motivate students maximally so it is recommended to provide more challenging questions, (4) The time division in the lesson plan should be given leeway so that the teaching and learning process can take place optimally, (5) by paying attention to the shortcomings and limitations in this study, it is suggested that further researchers be able to carry out further research using a more varied application of learning approaches so that the use of modules is more effective and further study is more interesting. 


\section{Acknowledgment}

In this section, we would like to thank all those who helped us with our research. Especially to the leadership of the boarding school, the principal, the educators, and students who have helped us from the initial stage to completing this research. We apologize if there are shortcomings, and we cannot mention all the parties involved.

\section{Bibliography}

Agustyaningrum, Nina, dan Yessy Yusnita. "Pengembangan Bahan Ajar Struktur Aljabar Berbasis Pendekatan Deduktif Untuk Meningkatkan Hot Skill Mahasiswa Universitas Riau Kepulauan (Unrika) Batam." Jurnal Dimensi 6, no. 2 (2017). https://doi.org/10.33373/dms.v6i2.1045.

Amirzan, Amirzan. "Pengembangan Model Pembelajaran Gerak Dasar Lokomotor Pada Siswa SD Kelas V." Journal Physical Education, Health and Recreation 2, no. 1 (2017): 85-96. https://doi.org/10.24114/pjkr.v2i1.7843.

Asbarin, Dita Armitha Sari, dan Kumillaela. "Kajian Morfologi Dan Pengaruhnya Terhadap Perubahan Makna (Analisa Buku Al 'Arabiyah Baina Yadaika)." Semnasbama (Seminar Nasional Bahasa Arab ) II 2 (2018): 344. http://prosiding.arab-um.com/index.php/semnasbama/article/view/208.

Departemen Pendidikan Nasional. Panduan Pengembangan Bahan Ajar. Jakarta: Direktorat Pembinaan Sekolah Menengah Atas, 2008.

Dodi, Limas. "Metode Pengajaran Nahwu Shorof; Ber-Kaca Dari Pengalaman Pesantren." Tafáqquh: Jurnal Penelitian Dan Kajian Keislaman 1, no. 1 (2013): 100-122.

http://jurnal.iaibafa.ac.id/index.php/tafaqquh/article/view/7.

Fakhrurrozy, M. Imam. "Nahwu Dan Shorof Perspektif Pembelajar Bahasa Kedua." Semnasbama (Seminar Nasional Bahasa Arab ) II 2 (2018): 103. https://prosiding.arab-um.com/index.php/semnasbama/article/view/186.

Isnainiyah. "Pengembangan Kitab Matan Al-Jurumiyah Dengan Pendekatan Induktif Untuk Siswi Madrasah Diniyah Nurul Ulum" 3 (2019): 1-19. https://prosiding.arab-um.com/index.php/semnasbama/article/view/422.

Kesuma, Mezan, dan Reni Puspita Sari. "Pengembangan Modul Sharaf Dengan Pendekatan Deduktif Di Pondok Modern Madinah Lampung." Studi Arab 11, no. 1 (2020): 27-36. https://doi.org/10.35891/sa.v11i1.1944.

Lasmiyati, Lasmiyati, dan Idris Harta. "Pengembangan Modul Pembelajaran Untuk Meningkatkan Pemahaman Konsep Dan Minat SMP." Pythagoras: Jurnal $\begin{array}{llllll}\text { Pendidikan Matematika 9, no. } 2 \text { (2014): } 161 . & \end{array}$ https://journal.uny.ac.id/index.php/pythagoras/article/view/9077.

Majid, Abdul. Perencanan Pembelajaran. Bandung: PT. Remaja Rosdakarya, 2008.

Mujab, Ahmad Saiful, Retno Purnama Irawati, dan Nailur Rahmawati. "Pengembangan Modul Bahasa Arab Berbasis Teori Psikologi Perkembangan Remaja Elizabeth B. Hurlock Kelas X MA." Lisanul Arab: Journal of Arabic Learning and Teaching 7, no. 1 (2018): 1-7. https://doi.org/10.15294/la.v7i1.26068.

Najah, Muhajirun. "Penerapan Pembelajaran Shorof Bagi Pembelajar Tingkat Pemula Menggunakan Metode Pemerolehan Bahasa." Al Mahāra: Jurnal 
$\begin{array}{llllll}\text { Pendidikan Bahasa Arab 5, no. } 1 & \text { (2019): } 117 .\end{array}$ https://doi.org/10.14421/almahara.2019.051-07.

Ntelok, I. F., I. B. N. Sudria, dan I. W. Suja. "Pengembangan Perangkat Pembelajaran Saintifik Dengan Model Pembelajaran Problem Solving Melalui Penalaran Deduktif Pada Topik Laju Reaksi." Jurnal Pendidikan Kimia Undiksha 2, no. 1 (2018): 28-39. https://doi.org/10.23887/jjpk.v2i1.21182.

Prastowo, Andi. Panduan Kreatif Membuat Bahan Ajar Inovatif. Yogyakarta: Diva Press, 2015.

Purnomo, Yusup. "Penerapan Metode Deduktif Pada Pembelajaran Nahwu Kelas 5 Pada Pondok Pesantren Al-Ishlah, Alislami Assalafi, Mangkangkulon, Semarang (Pembelajaran Fi'il Muta'addi Dan Fi'il Lazim)." Skripsi, IAIN Walisongo, 2012. http://eprints.walisongo.ac.id/727/.

Rahmawati, R. A. Putri, dan Novita Rahmi. "Analisis Kesalahan Morfologi Dalam Insya." An Nabighoh: Jurnal Pendidikan Dan Pembelajaran Bahasa Arab 22, no. 02 (2020): 243. https://doi.org/10.32332/an-nabighoh.v22i02.2311.

Ridlo, Ubaid. "Model Pembelajaran Bahasa Arab Materi Al-Qawa'id al-Nahwiyyah." $\begin{array}{lllll}\text { Al-Ma'rifah } & 12, & \text { no. } & 2 & \text { (2015): }\end{array}$ https://doi.org/10.21009/almakrifah.12.02.05.

Sadjati, Ida Malati. "Hakikat Bahan Ajar," dalam Pengembangan Bahan Ajar. Jakarta: Universitas Terbuka, 2012.

Sanjaya, Wina. Media Komunikasi. Jakarta: Kencana Prenada Media Group, 2012.

Septyenthi, Sica, Aprizal Lukman, dan Upik Yelianti. "Pengembangan Modul Pembelajaran IPA Berbasis Entrepreneurship Di SMK Negeri 2 Kota Jambi." Edu-Sains: Jurnal Pendidikan Matematika Dan Ilmu Pengetahuan Alam 3, no. 2 (2014). https://doi.org/10.22437/jmpmipa.v3i2.1893.

Setianingsih, Enik, Widha Sunarno, dan Sukarmin Sukarmin. "Pengembangan Modul Pembelajaran Dinamika Gerak Berbasis Inkuiri Terbimbing Untuk Siswa Kelas X SMA/MA." INKUIRI: Jurnal Pendidikan IPA 7, no. 2 (2018): 220. https://doi.org/10.20961/inkuiri.v7i2.22978.

Sugiyono. Metode Penelitian Pendidikan (Pendekatan Kualitatif, Kuantitatif dan $R \& D)$. Bandung: Alfabeta, 2012.

Supriadi, Agus, Akla Akla, dan J. Sutarjo. "Problematika Pengajaran Bahasa Arab Di Madrasah Aliyah." An Nabighoh: Jurnal Pendidikan Dan Pembelajaran Bahasa Arab 22, no. 02 (2020): 211. https://doi.org/10.32332/annabighoh.v22i02.2314. 
